最新の神経画像検査を用いた側頭葉てんかんの多機能画像診断・手術

\author{
前原 健寿 $^{1)}$, 田中 洋次 ${ }^{1)}$, 青柳 傑1), 成相 直 $^{1)}$, 河野 能久 ${ }^{1)}$, 石井 賢二 ${ }^{2)}$ \\ 石渡 喜一2), 大野 喜久郎1) \\ 1）東京医科歯科大学脳神経外科, 2) 東京都健康長寿医療センター研究所神経画像研究チーム
}

\title{
Multi-image Fusion Diagnosis and Guided-surgery for Temporal Lobe Epilepsy based on Recent Neuroradiological Examinations
}

\author{
Taketoshi Maehara, M.D. ${ }^{1)}$, Yoji Tanaka, M.D. ${ }^{1)}$, Masaru Aoyagi, M.D. ${ }^{1)}$, Tadashi Nariai, M.D. ${ }^{1)}$, \\ Yoshihisa Kawano, M.D. ${ }^{1)}$, Kenji Ishii, M.D. ${ }^{2}$, Kiichi Ishiwata, M.D. ${ }^{2}$, and Kikuo Ohno, M.D. ${ }^{1}{ }^{\prime}$ \\ 1) Department of Neurosurgery, Tokyo Medical and Dental University, 2) Positron Medical Center, Tokyo Metropolitan Institute of \\ Gerontology
}

Neuroradiological examinations play an important role in diagnosis and surgery for epilepsy patients. Since the introduction of the 3T MR imager, we have had the means to easily perform high-resolution MR imaging, diffusion tensor imaging (DTI), and MR spectroscopy. These MR imaging modalities provide important information on focus diagnosis and surgery for temporal lobe epilepsy. Safe and accurate temporal lobe epilepsy surgery can be accomplished by simulating the surgery preoperatively based on three-dimensional fusion images and then performing the surgery under multi-image guidance with PET and SPECT.

(Received January 24, 2012 ; accepted February 20, 2012)

Key words : temporal lobe epilepsy, neuroimaging, 3T MRI, multi-image fusion, navigation Jpn J Neurosurg（Tokyo）21:712-720, 2012

\section{はじめに}

神経画像検査は，側頭葉てんかんの焦点診断および外 科治療に重要な役割を有している。 なかでも MRI は, 形 態異常のみならず機能異常も描出でき, PET・SPECT 等 の核医学検査とともに焦点診断に用いられている。最近 では MRI を用いた 3 次元融合画像の作成, 脳機能局在 や連絡紼維の描出を加えた多機能画像の作成が, 正確で 安全なてんかんの手術に役立っている7)11).

最近のこのような神経画像検査の進歩は, コンピュー 夕ー技術の発展や解析ソフトの登場, 3T MRI が普及し たことなどが要因となっている。ささらに 7T MRI による 高解像度画像の登場 ${ }^{4}$ や解析法のさらなる進歩によっ
て, 神経画像検査による焦点診断法や 3 次元融合画像を 用いた多機能画像解析は今後も発展し続けるものと考元 られる。

今回対象とした側頭葉てんかんは，てんかん外科治療 の中で最も代表的な疾患であると同時に，手術のために は側頭葉の微小解剖の習熟が必要な疾患である。神経画 像検査を駆使して，海馬扁桃体の構造のみならず，脈絡 叢や海馬采との関係，さらには大脳脚，視床との関係お よび動眼神経, 前脈絡叢動脈, 後大脳動脈の走行などを 描出し理解することは，治療のうえで重要なことと考え られる。

本稿では側頭葉てんかん外科治療患者を対象として, 従来行わ机てきた神経画像診断に加え, 当院に 3T MRI

連絡先：前原健寿, $\bar{\top}$ 113-8519 文京区湯島 1-5-45 東京医科歯科大学脳神経外科

Address reprint requests to: Taketoshi Maehara, M.D., Department of Neurosurgery, Tokyo Medical and Dental University, $1-5-45$ Yushima, Bunkyo-ku, Tokyo 113-8519, Japan 


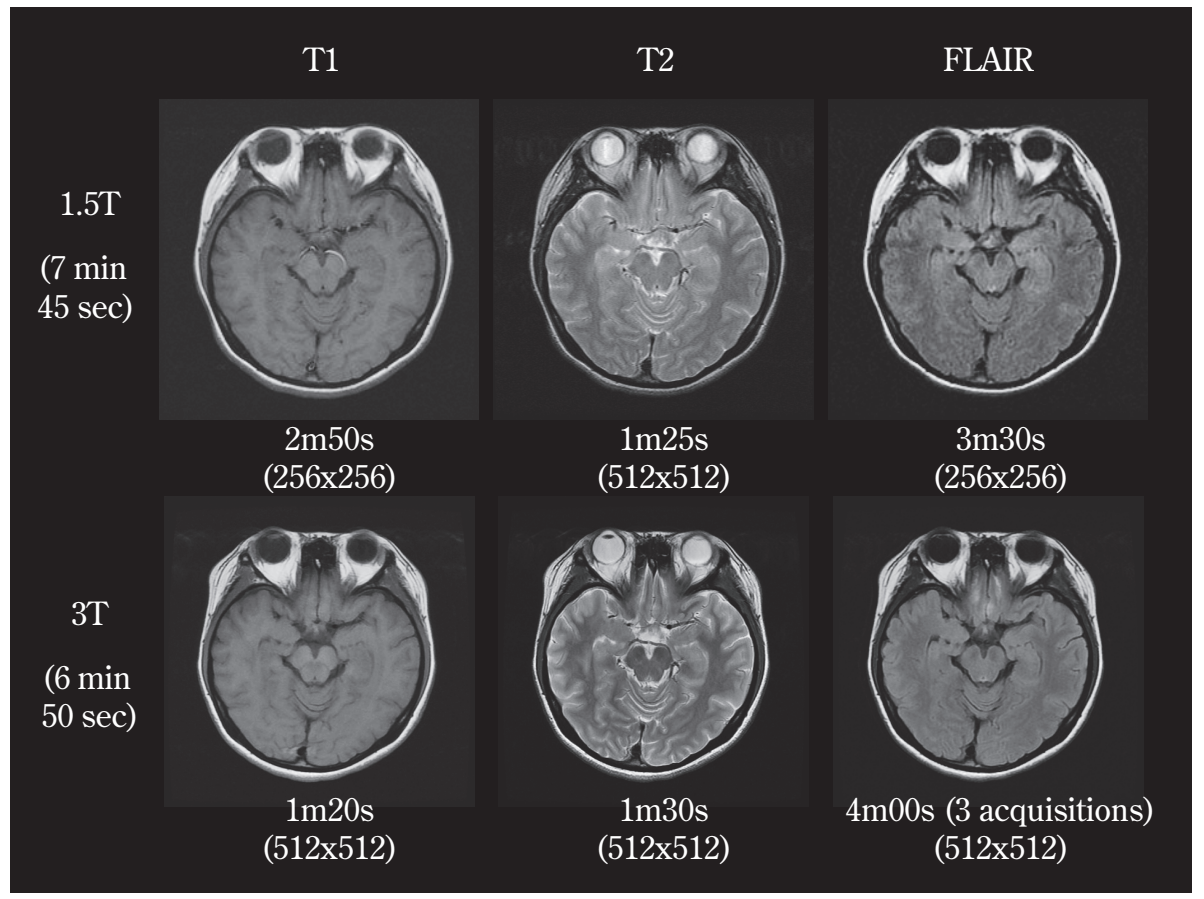

Fig. 1 1.5T and 3T MRI

1.5T (upper) and 3T (lower) axial MRIs of the same patient (left: $\mathrm{T} 1$-weighted, middle : FLAIR, right: T2-weighted).

3T high resolution

$(7 \mathrm{~min} 30 \mathrm{sec})$
$3 \mathrm{~T}$

(2min30sec)
$1.5 \mathrm{~T}$

$(2 \min 30 \mathrm{sec})$

healthy side : left

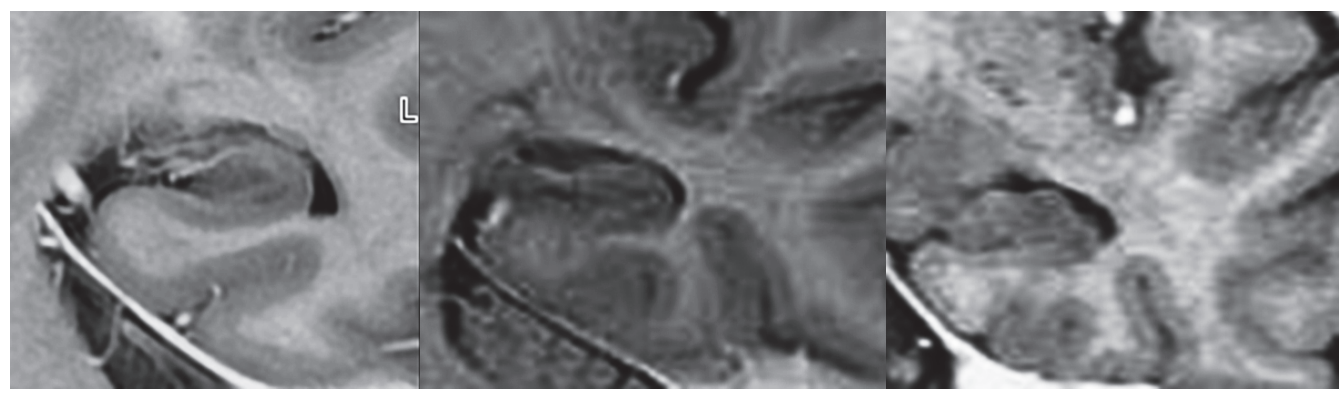

affected side : right

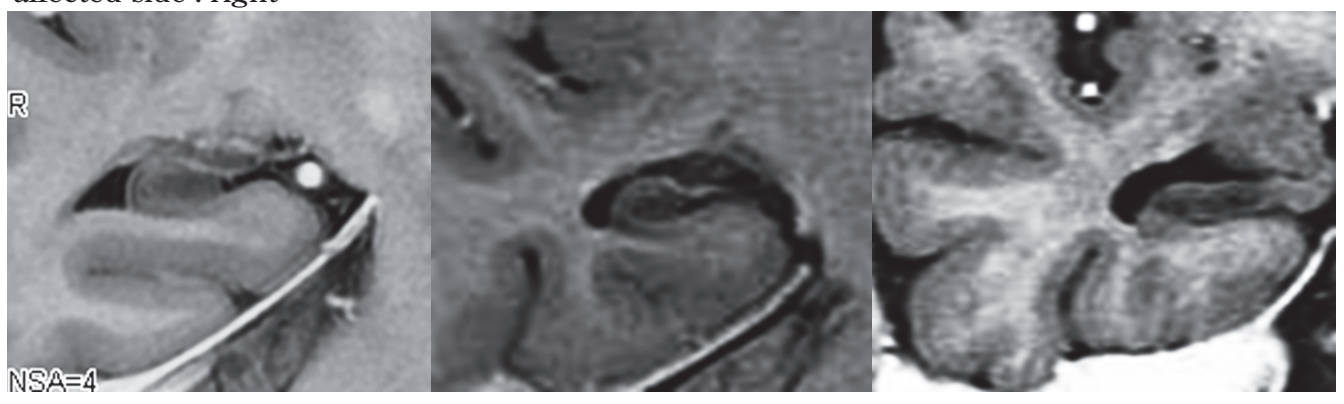

Fig. 2 Hippocampus of patients with right temporal lobe demonstrated by $1.5 \mathrm{~T}$ and 3T MRI

T2-reverse images of different patients with right temporal lobe epilepsy (right: $3 \mathrm{~T}$ high resolution, middle $: 3 \mathrm{~T}$, left $: 1.5 \mathrm{~T})$. 


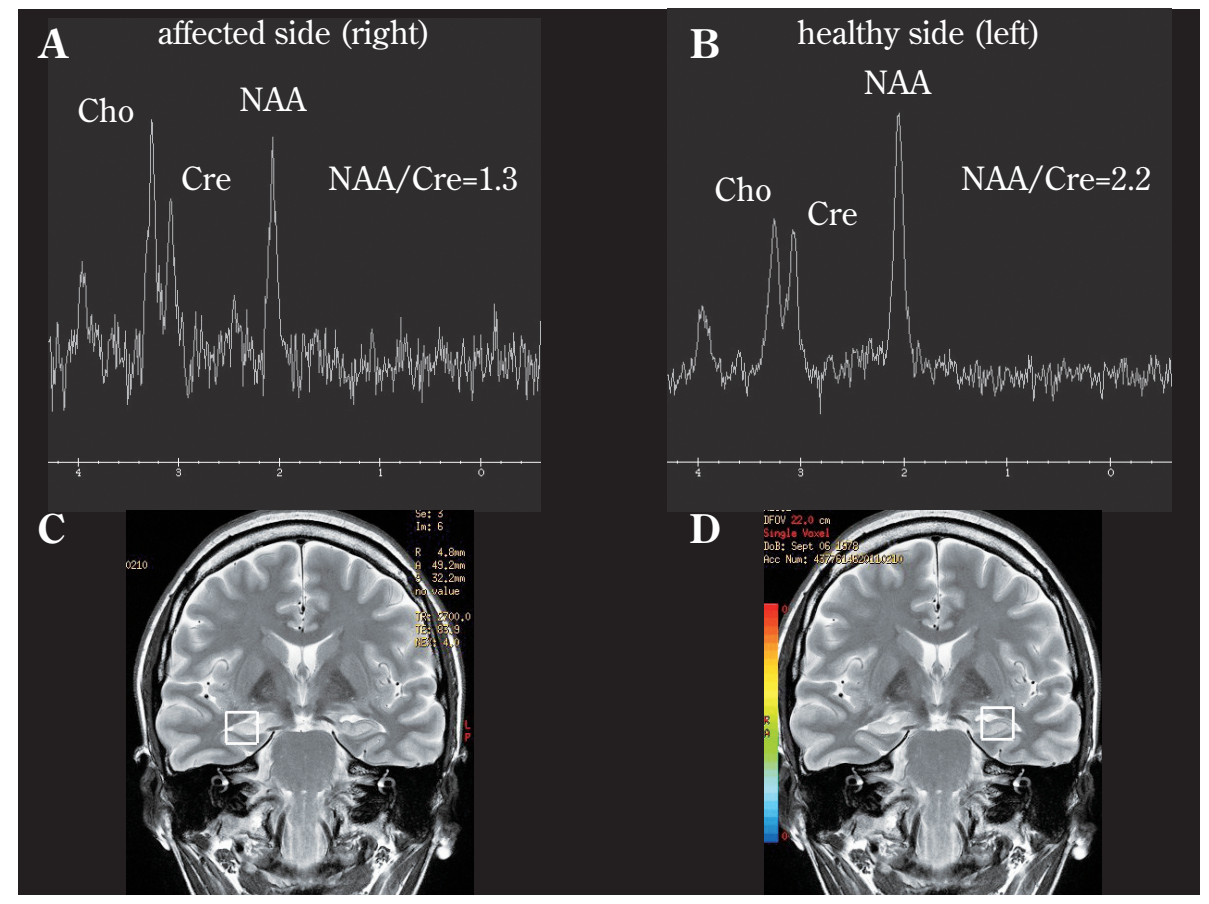

Fig. 3 MRS of a patient with right temporal lobe epilepsy A, C : right (affected) side, B, D : left (healthy) side

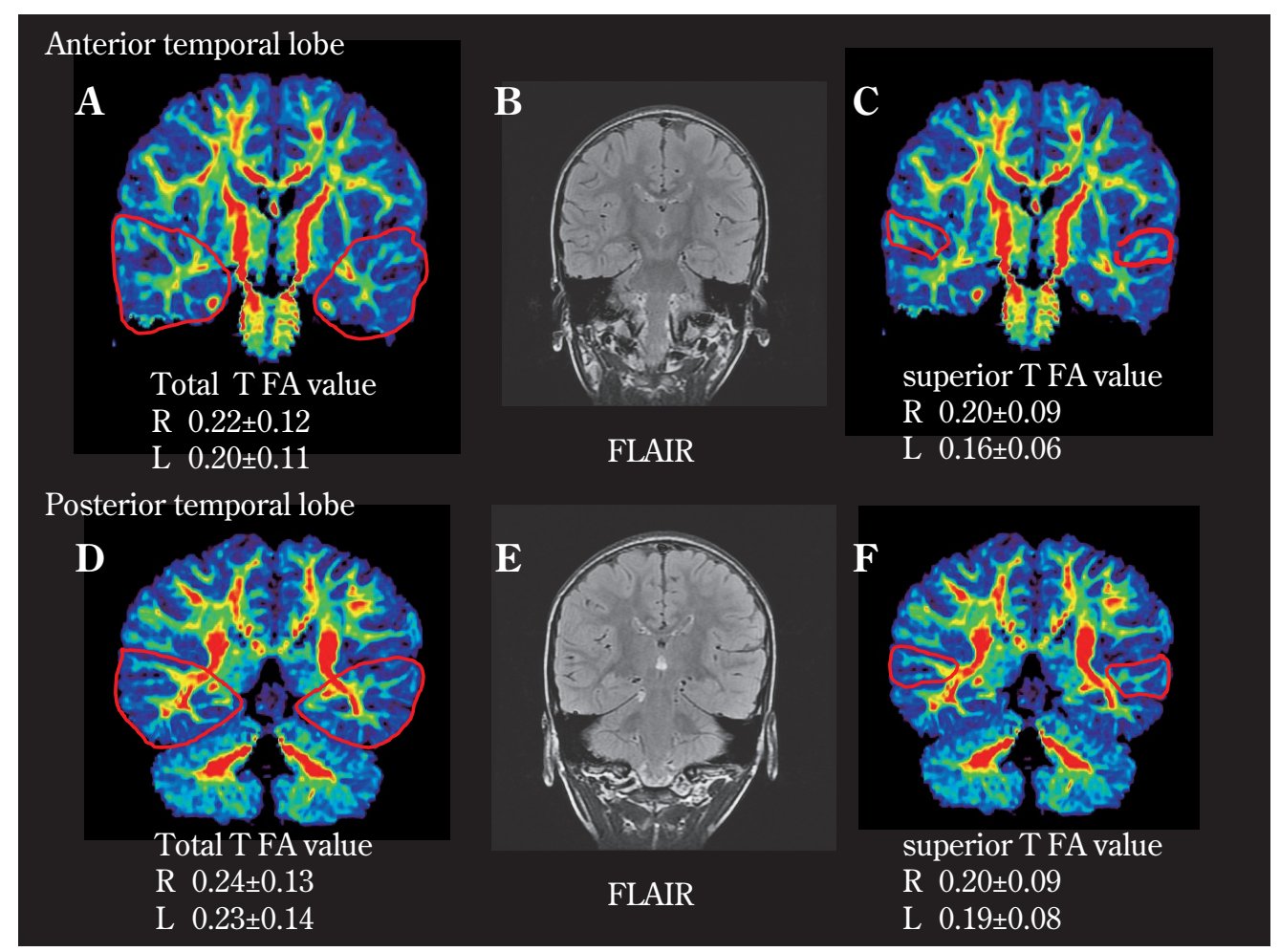

Fig. 4 DTI \& MRI (FLAIR) of a patient with left temporal lobe epilepsy

FA values are calculated in the whole temporal lobe (A: anterior, $\mathbf{D}:$ posterior) and superior ( $\mathbf{C}$ : anterior, $\mathbf{F}$ : posterior) temporal lobe. FLAIR images of MRI demonstrate the blurring of gray and white matter in the left temporal lobe (B : anterior, $\mathbf{E}:$ posterior). 


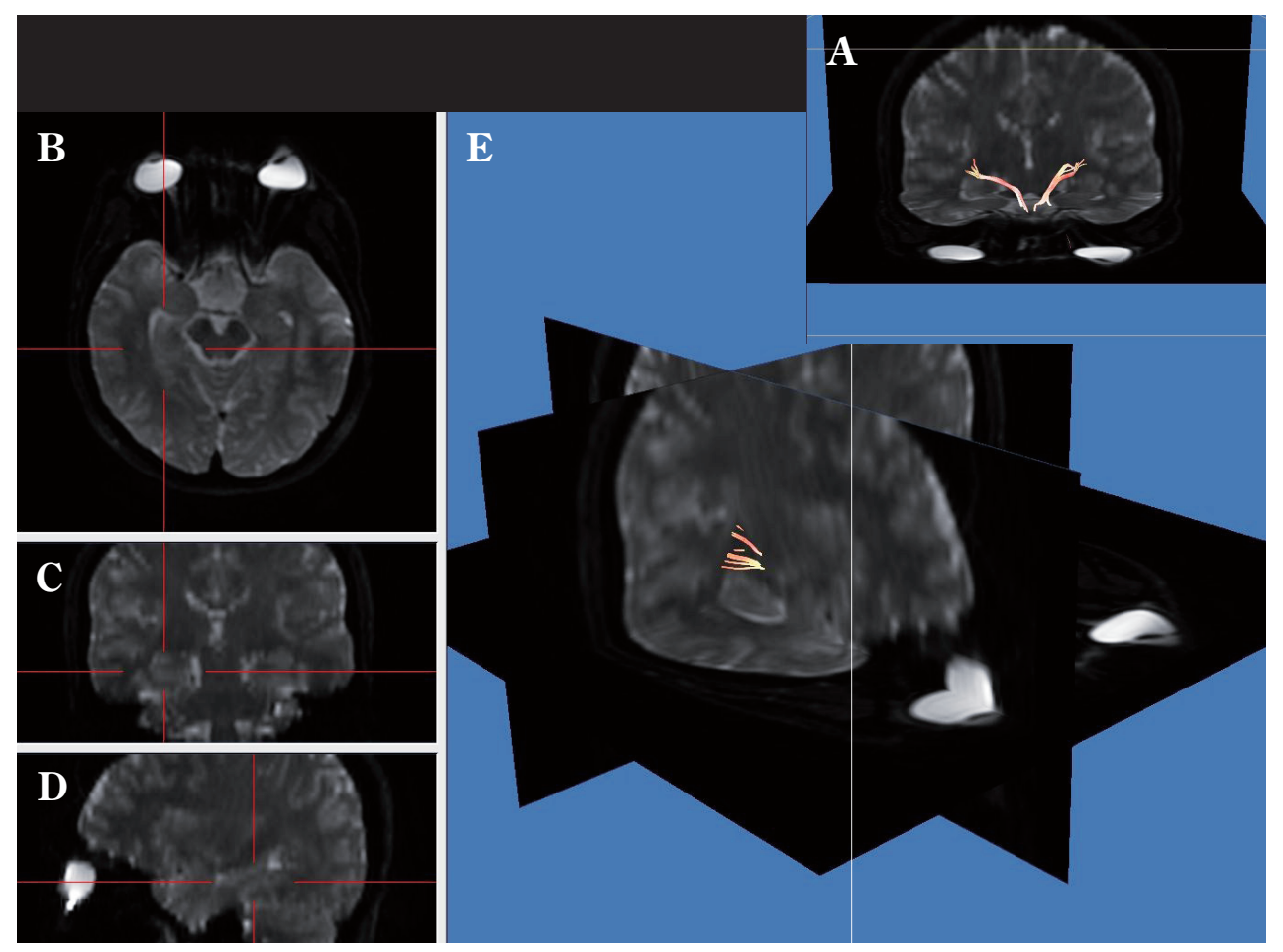

Fig. 5 Fiber tracking of the optic pathway

Section of fiber tracking of the optic pathway using a dTV diffusion tension visualizer system developed by the Department of Radiology at Tokyo University in a patient with right temporal lobe epilepsy (A). Section at the posterior part of the inferior horn (E) : an axial view (B), a coronal view (C), a sagittal view (D).

が導入された 2010 年以後に施行している最新というよ りはむしろ最近の神経画像検査の実際を提示する ${ }^{8)}$.さ らに，側頭葉てんかん手術シミュレーションとしての 3 次元融合画像 ${ }^{5)}$ と多機能画像 ${ }^{11)}$ を用いた術前画像の有用 性も紹介したい.

\section{神経画像検査による側頭葉てんかんの 焦点診断の意義}

てんかんは脳の神経細胞の電気生理学的異常によって 引き起こされる病態であるため, 基本となる脳波検査に 発作型と MRI などの神経画像検査を加えて総合的に焦 点診断が行われる。 Luders ${ }^{6}$ は部分てんかんでみられる 脳病変を分類し, MRI はてんかんに関連した病変を描出 し, PET・SPECT は脳機能異常部位を描出するに過ぎな いとしている.しかし一方で, MRI で病変が描出される ことは，てんかん手術の成績を左右する重要な因子の一 つとされている ${ }^{15)}$. また切除で発作が消失する領域はて んかん原生領域と定義されているが，単一の検査でこの 領域が決定できるわけではない。本稿では神経画像検査
による焦点という用語をしばしば用いるが，必ずしもて んかん原生領域や発作起始部位を指すわけではないこと に留意してほしい.

\section{神経画像検査による通常の 側頭葉てんかんの焦点診断}

側頭葉てんかんの画像診断では，海馬硬化の診断が最 も重要である. MRI で正確に海馬の萎縮や信号変化を判 定するためには, 通常の axial, coronal 画像のみでは不十 分で，海馬の先端から後方部分までを詳細に観察できる ように斜台に平行に切り出した coronal 画像や, 海馬の 長軸方向に沿った axial 画像が必要である。撮像法とし ては FLAIR 画像が有用だが, 皮髄境界のコントラストを 明瞭にした 3D-short tau inversion recovery (STIR) の有 用性も報告されている3).

核医学検査では F-18 fluorodeoxyglucose (FDG)-PET による間欠期の脳代謝低下部位の描出が焦点診断に有用 で，中枢性ベンゾジアゼピン受容体拮抗薬を用いた C11 flumazenil (FMZ)-PET も鋭敏な焦点診断検査であ 

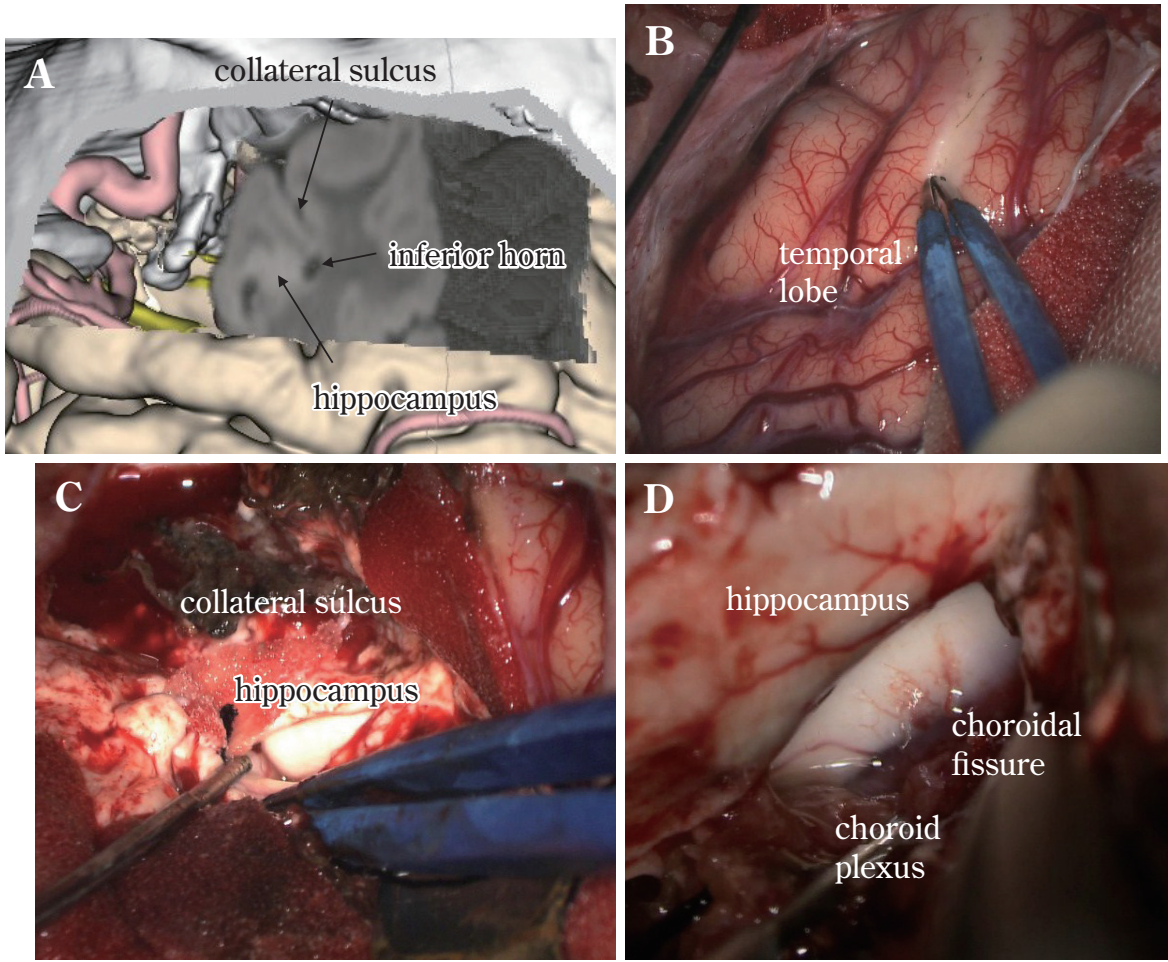

Fig. 6 Simulation and intraoperative photographs of a right anteromedian temporal lobectomy

Three-dimensional multi-image-fusion images (A) and photographs during the operation (B: lateral temporal resection, $\mathbf{C}$ : collateral sulcus and hippocampus, $\mathbf{D}$ : choroidal plexus and choroidal fissure).

る。ただし FMZ-PET は保険未承認で, 保険承認を受け た I-123 Iomazenil (IMZ) -SPECT も焦点診断に有用であ る. また発作時に焦点の脳血流が増加することを利用し た SISCOM は, 発作時の情報がえられる画像検査として 特殊な位置を占めている。

\section{側頭葉てんかんに対する当科の神経画像検査}

\section{MRI}

当院では SIGNA HDxt 1.5T と 3T MRI(GE)を使用し, T1，T2，FLAIR の axial 画像と斜台に平行な coronal 画 像，MRA，合成画像作成用の multiplanar reconstruction （MPR）を撮影している。撮像時間は 1.5 T MRI では約 17 分, 3T MRI では約 14 分である。これとは別に $3 \mathrm{~T}$ MRI でMRS, DTI を撮影し, MRS を左右海馬の 2 力所 で測定した場合の撮像時間は約 18 分である.

高精度画像や撮像時間には，マトリクスや加算回数が 関与する. 1.5T では T1 強調像と FLAIR 画像では $256 \times$ 256 のマトリクス, $\mathrm{T} 2$ 強調像では $512 \times 512$ の 1 回撮影 で 7 分 45 秒の撮像時間を要している. $3 \mathrm{~T}$ のマトリクス

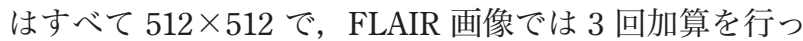
ているが合計 6 分 50 秒で, より高解像度画像がえられ ている (Fig. 1).

\section{PET - SPECT}

FDG-PET の検査では当日，少なくとも検査 3 時間前 と検査中に発作がなかったことを確認する. FDG-PET は，静注 40 分後に 5 分間の撮影を行う。FMZ-PET は 静注 20 分後に 20 分間の撮影を行う。IMZ-SPECT は静 注 3 時間後に 30 分撮影を行う.

診断には，視覚的診断に加え正常被験者と比較した統 計学的解析が有用である. 正確な診断には, 機種ごと, 年齢ごとのデー夕による比較が必要である。われわれは フリーのソフトウェアである SPM2（Wellcome Department of Imaging Neuroscience，London，U.K.) を用いた statistical parametric mapping (SPM) 解析を PET 検査の 客観的な診断として用いている。簡便な方法としては, たとえば IMZ-SPECT では無償ソフトの INEUROSTAT （日本メジフィックス株式会社）を用いた 3D-SSP 解析 がある.SISCOM の一番の問題は，放射線管理区域で発 


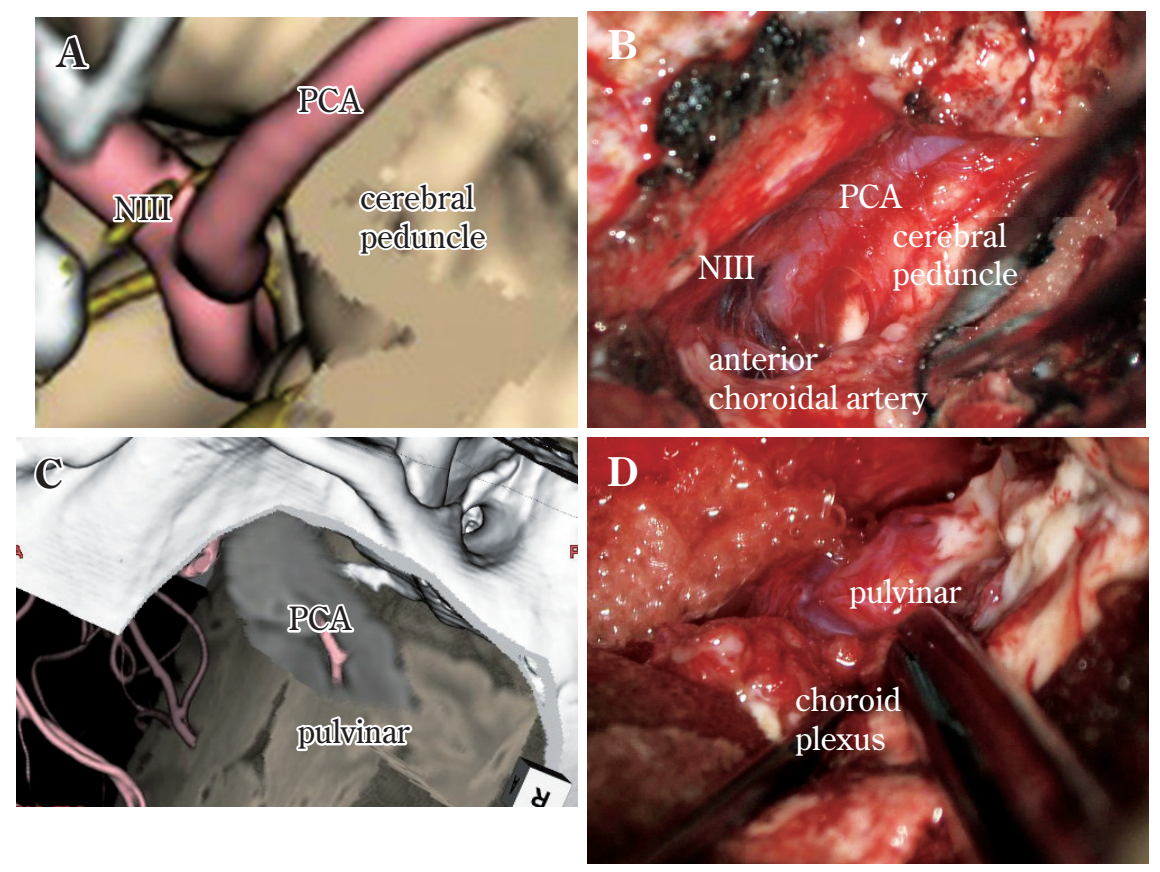

Fig. 7 Simulation and intraoperative photographs of a right anteromedian temporal lobectomy

Three-dimensional (3D) multi-image fusion MRIs and photographs during the operation.

3D image (A) and (B) photograph after removal of the hippocampal head. 3D image (C) and (D) photograph after removal of the hippocampal body.

作を確認し静注しなければならないことである．解析に は無償のソフトである SISCOM2009（富士フィルム RI ファーマ株式会社）が有用である7).

\section{T MRI 導入による側頭葉てんかんの 画像検査}

\section{1 海馬の解剖学的構造の描出}

高解像度の海馬構造描出には, 高解像マトリクスと加 算撮影を行い $\mathrm{S} / \mathrm{N}$ 比を上げることが必要である。 Fig. 2 に T2-reverse 画像を用いた右側頭葉てんかん患者の海 馬を示す. 3T MRI では, 1.5Tより精細な海馬構造が描 出され, さらに 3 回加算を行うことでよりきれいな画像 がえられている。ただし撮像時間は 7 分 30 秒かかり, 体動のアーチファクトを避けるためには患者の忍耐が必 要となる.

\section{MRS}

3T MRI を用いることで，1.5T では撮影に工夫を要し た海馬の MRSも安定して撮影できるようになった。 $\mathrm{NAA} / \mathrm{Cre}$ あるいは $\mathrm{NAA} / \mathrm{chol}$ 值の低下が焦点診断に有
用とされている (Fig. 3)。また機種によっては GABA や glutamate の測定も可能で, 焦点診断に重要な役割を果た すと期待されている16).

\section{DTI}

拡散テンソル解析は特定の白質路の可視化 ${ }^{10)}$ と, 白質 の密度や病的変化に関連した指標を定量的に解析するこ とを可能にし ${ }^{9)}$, 側頭葉てんかんの病態解析にも広く応 用されている112).

Fig. 4 に脳形成障害に起因した難治てんかん症例を示 す. FLAIR 画像で左側頭葉の皮質白質境界が不明瞭化し ているが，範囲を見きわめるのは容易ではない，DTI で FA map を作成し絶対值を計算すると, 患側の側頭葉前 方では FA 值低下を認めるが，側頭葉後方では FA 值低 下は軽度であることがわかり，切除域を決定するうえで は重要な所見の一つであった。

視放線の損傷による視野障害の出現は側頭葉てんかん 手術の合併症の一つである。視放線の経路には個人差が あるため，下角を開放した場合に視放線がどの位置に出 現するかをあらかじめ知っておくことが視野障害の回避 には重要である ${ }^{17)}($ Fig. 5). 


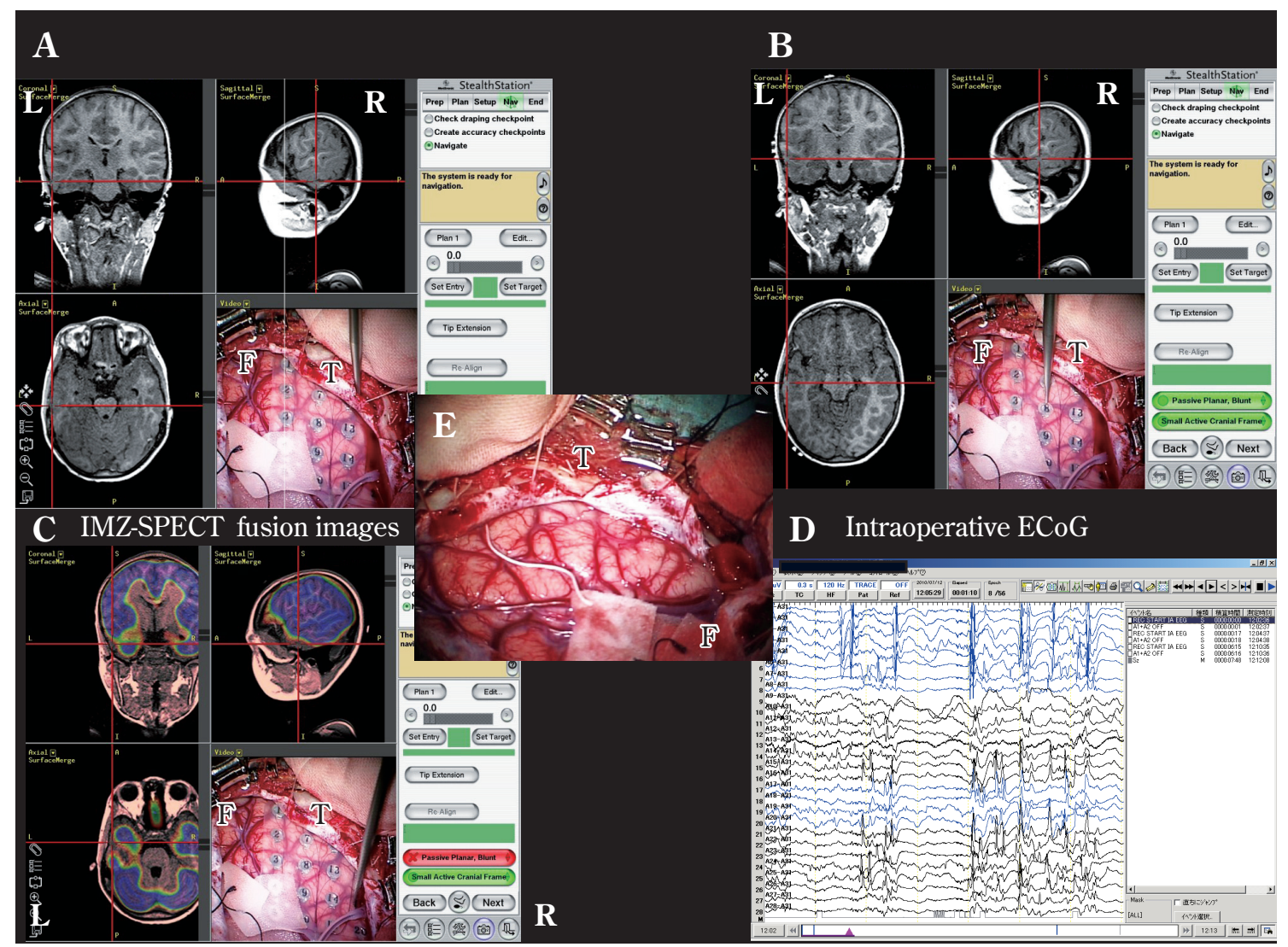

Fig. 8 Multi-image guided epilepsy surgery

Images taken during intraoperative navigation surgery using Stealth Station (MACH 4.0). A probe indicates contact $12(\mathbf{A})$, contact $8(\mathbf{B})$, and contact $19(\mathbf{C}$ : IMZ-SPECT fusion image [low-uptake area suggests the epileptogenic area]) of the intracranial electrodes. Intracranial ECoG demonstrates diffuse spikes (D). The white thread indicates the resection line (E).

\section{手術シミュレーション}

術前画像検査でえられたさまざまな情報を統合し 3D image 画像を作成することで, 綿密な手術戦略を構築す ることができる．3D 画像を任意の方向に回転し，アプ ローチの方向や手術手順に沿った画像を作成すると内部 の重要構造の位置が確認できる。多機能の $3 \mathrm{D}$ 合成画像 を用いた手術シミュレーションは，手術チームの手順確 認にも有用である.

具体的な方法としては，まず MPR 画像を撮影し， MRI，FLAIR 画像から脳の血管や神経を同定して 3 次元 融合画像を作成する. 3D 画像処理ソフトには, ZIOSTATION（Zio soft）を用いている。ただし現状では，画像 作成や切り出しは自動的に行える作業ではなく, コン ピューター操作と同時に手術に精通した脳外科医が作成 に関与する必要がある ${ }^{5)}$.

右側頭葉てんかん患者の前内側側頭葉切除の手術シ
ミュレーションを示す13)14)。この症例では，1）T2 以下 で先端から $4 \mathrm{~cm}$ の側頭葉先端切除を行い，2）側副溝の 前方に沿って後内側へ向かい下角に到達し，海馬，扁桃 核を明らかにし，3）下角を後方に展開し，(扁桃核の一 部を切除して) 脈絡叢および脈絡裂を明らかにした (Fig. 6).4）脈絡裂から側頭葉先端方向に向かい，海馬采を 離断し，5）海馬の前方，後方を trimming し海馬頭部を 切除する. 切除後は大脳脚が明らかになり, 前方では動 眼神経，後大脳動脈が確認でき，扁桃体前方内側部分の 切除により前脈絡叢動脈が確認できる。6）後内側へ向 かい，海馬体部を切除すると視床枕を確認できる（Fig. 7).

さらにDTI でえられた視放線の融合画像や, 左側頭葉 てんかんでは functional MRI などでえられた言語野の融 合画像を作成することで，より安全な手術シミュレー ションが可能となる. 


\section{多機能画像を用いた術中ナビゲーション手術}

側頭葉てんかんでは海馬切除の有無が，手術戦略，治 療成績に重要であるため術中ナビゲーションの有用性は 限られている。ただし, 腫瘍性病変や脳形成障害が原因 の難治てんかん症例では, 側頭葉外側の切除範囲が問題 となり術中ナビゲーションの有用性は高い ${ }^{11}$. 特に小児 や精神発達上の問題を有する患者では電極留置術による 発作時皮質脳波の記録が困難であるため, 術中間欠期脳 波所見と画像所見の両者から切除域を決定する必要があ る。ただし，ナビゲーション手術には, brainshift という 不可避の問題がある ${ }^{1112)}$ ため, 現時点では術前の使用が 適当と考えている. 今回, 脳形成障害が原因の左側頭葉 てんかん小児例を対象に当院で施行している多機能画像 を用いた術中ナビゲーションの概略を提示する7) (Fig. 8). 自験では PET/SPECT 画像と MRI との重ね合わせ を行い, 術中皮質脳波所見と対比したナビーション手術 を行うことで術後 3 年以上経過した MRI 病変を有する 14 症例で, 13 例が Engel class I で 8 例が抗てんかん薬 中止と良好な成績がえられている8).

手順としては，1）まずT1，FLAIR，T1-gadorinium のなかで病変を描出するのに最も適した撮像法を選択 し, MPR 画像を撮影する。次に Dr. view（旭化生情報, 東京）を用いて PET, SPECT 等と重ね合わせた画像を 作成する（本症例では T1 の MPR 画像を撮像し, IMZSPECT の取り込み低下部位を MRI に重衩た)。次に，2） ナビゲーション（Stealth Station MACH 4.0）を設置し開 頭後に, 硬膜下電極を用いて皮質脳波測定を行う。最後 に，3）皮質脳波のスパイクが出現する電極を確認して 電極上でナビゲーションを行い, MRI 病変, PET・ SPECT 異常出現部位と比較し切除範囲を決定する (本症 例では MRI 異常部位は, 皮質脳波スパイク出現部位とほ ぼ同じ範囲で, IMZ-SPECT の取り込久低下部位は MRI 異常部位内に限局していた)。4）切除後に再度皮質脳波 測定を行い，遺残スパイクを記録し，追加切除あるいは multiple subpial transection (MST) の追加を検討する (左側頭葉内側を含む側頭葉切除を行い, 術後脳波でも遺 残スパイクは認めなかった).

抗てんかん薬は継続中であるが, 術後約 2 年で seizure-free の成績がえられている。

\section{おわりに}

3T MRI でえられた高解像度画像，特殊撮影を用いた 多機能画像, 3 次元融合画像は側頭葉てんかんの診断 •
手術に重要な役割を果たしている，今後，7T MRI や新 たな解析法の導入で，側頭葉てんかんにおける神経画像 診断の重要性はますます増していくことと考えられる.

\section{文 献}

1) Assaf BA, Mohamed FB, Abou-Khaled KJ, Williams JM, Yazeji MS, Haselgrove J, Faro SH : Diffusion tensor imaging of the hippocampal formation in temporal lobe epilepsy. AJNR Am J Neuroradiol 24: 1857-1862, 2003.

2) Gross DW: Diffusion tensor imaging in temporal lobe epilepsy. Epilepsia 52 (Suppl 4) : 32-34, 2011.

3) Hashiguchi K, Morioka T, Murakami N, Suzuki SO, Hiwatashi A, Yoshiura T, Sasaki T: Utility of 3-T FLAIR and $3 \mathrm{D}$ short tau inversion recovery MR imaging in the preoperative diagnosis of hippocampal sclerosis: Direct comparison with 1.5-T FLAIR MR imaging. Epilepsia 51: 1820-1828, 2010.

4) Henry TR, Chupin M, Lehericy S, Strupp JP, Sikora MA, Sha ZY, Ugurbil K, Van de Moortele PF: Hippocampal sclerosis in temporal lobe epilepsy: findings at $7 \mathrm{~T}$ (1). Radiology 261: 199-209, 2011.

5）金 太一，小山博史，庄島正明，辛 正廣，斉藤延人： 3 次元融合画像とシミュレーション. 脳外誌 $20: 238-$ $246,2011$.

6) Luders H, Awad I: Conceptual considerations. in Luders H (ed) : Epilepsy Surgery. New York, Raven Press, 1992, pp.51-62.

7) Maehara $T$ : Epilepsy surgery and focus detection utilizing imaging of preoperative multi-modal examinations. No Shinkei Geka 35 : 1053-1065, 2007.

8) Maehara $T$ : Intraoperative monitoring of epileptic foci: usefulness of multimodality image-guided epilepsy surgery performed in combination with electrocorticography. Brain Nerve 63: 321-329, 2011.

9) Mascalchi M, Filippi M, Floris R, Fonda C, Gasparotti R, Villari N: Diffusion-weighted MR of the brain: methodology and clinical application. Radiol Med 109: 155-197, 2005.

10) Mori S, Crain BJ, Chacko VP, van Zijl PC: Three-dimensional tracking of axonal projections in the brain by magnetic resonance imaging. Ann Neurol 45: 265-269, 1999.

11) Murphy MA, O’Brien TJ, Morris K, Cook MJ : Multimodality image-guided surgery for the treatment of medically refractory epilepsy. J Neurosurg 100: 452-462, 2004.

12) Ohue $S$, Kumon $Y$, Nagato $S$, Kohno $S$, Harada H, Nakagawa K, Kikuchi K, Miki H, Ohnishi T: Evaluation of intraoperative brain shift using an ultrasound-linked navigation system for brain tumor surgery. Neurol Med Chir (Tokyo) 50:291-300, 2010.

13) Shimizu H, Ohta Y, Suzuki I, Ishijima B, Sugishita M: Lateral temporal polar approach to mesial temporal lesions. Neurol Med Chir (Tokyo) 33:360-364, 1993.

14) Spencer DD : Anteromedial temporal lobectomy: directing the surgical approach to the pathologic substrate. in Spencer SS, and Spencer DD (eds): Surgery for epilepsy. Boston, Blackwell Scientific Publications, 1991, pp.129148.

15) Spencer SS : MRI and Epilepsy Surgery. Neurology 45 : 1248-1250, 1995.

16) Widdess-Walsh P, Diehl B, Najm I: Neuroimaging of focal 
cortical dysplasia. J Neuroimaging $16: 185-196,2006$.

17) Winston GP, Mancini L, Stretton J, Ashmore J, Symms MR, Duncan JS, Yousry TA: Diffusion tensor imaging trac- tography of the optic radiation for epilepsy surgical planning: a comparison of two methods. Epilepsy Res 97: 124-132, 2011.

要

最新の神経画像検査を用いた側頭葉てんかんの多機能画像診断・手術

前原 健寿 田中 洋次 青柳 傑 成相 直

河野 能久 石井 賢二 石渡 喜一 大野喜久郎

てんかんの焦点診断・手術において, 神経画像検査の果たす役割は大きい. 最近, 日常診療に 3T MRI が導入されたことで, 容易に高精度画像撮影や, DTI, MRS 等の特殊撮影が行えるようになった. 側頭葉てんかんにおいては, 焦点診断の向上に加え, 3 次元融合画像を用いた手術シミュレーション や, PET・SPECT 所見を加えた多機能画像診断手術が安全で確実な手術に寄与すると考えられる.

脳外誌 $21: 712-720,2012$ 